\title{
RISIKO PEMBIAYAAN MODAL KERJA DI BANK JATIM SYARIAH'
}

\author{
Taufan Indrasasmita \\ Departemen Ekonomi Syariah - Fakultas Ekonomi dan Bisnis - Universitas Airlangga \\ Email: taufan-i-s-11@feb.unair.ac.id \\ Imron Mawardi \\ Departemen Ekonomi Syariah - Fakultas Ekonomi dan Bisnis - Universitas Airlangga \\ Email: imron.mawardi@feb.unair.ac.id
}

\begin{abstract}
:
The results showed that the risk management process of working capital financing at Bank Jatim Syariah consists of risk identification, risk analysis, risk control and risk evaluation. The main risks in working capital financing are credit risk, reputation risk, and liquidity risk. Bank Jatim Syariah mitigates credit risk by analyzing risk using six methods of Bank Jatim Syariah analysis, which are management analysis, financial analysis, character analysis, facility analysis, business environment condition analysis and collateral analysis or guarantee. After conducting this analysis, Bank Jatim Syariah uses $3 R$ control, which is rescheduling, restructuring and reconditioning.
\end{abstract}

Keywords: Risk, Financing, Bank Jatim Syariah

\section{PENDAHULUAN}

\section{Latar Belakang}

Sistem perbankan memiliki fungsi diantaranya menyelenggarakan mekanisme lalu lintas pembayaran yang efisien, cepat dan akurat. Selain itu perbankan juga berperan sebagai perantara antara pihak yang kelebihan dana dan yang kekurangan, digunakan untuk kegiatan yang lebih produktif. Peran tersebutlah yang membuat perbankan disebut sebagai lembaga perantara keuangan atau financial intermediary institution (Sulhan dan Siswanto, 2008:3). Lembaga perbankan sekarang dipisahkan menjadi 2, yaitu perbankan konvensional dan peerbankan syariah. Perbankan syariah di Indonesia sendiri terhitung masih baru dalam dunia perekonimian Indonesia. Perbankan syariah bisa dijadikan solusi bagi masyarakat Indonesia ditengah makin gencarnya perbankan konvensional dalam menjajakan produknya. Dalam pelaksanaannya, perbankan syariah lebih ditekankan untuk menghindari penggunaan bunga (riba) yang biasanya ada pada perbankan konvensional.

Menurut Undang-Undang No. 21 tahun 2008 tentang perbankan syariah, Bank Syariah adalah bank yang menjalankan kegiatan usahanya berdasarkan prinsip Syariah dan menurut jenisnya terdiri atas Bank Umum Syariah dan Bank Pembiayaan Rakyat Syariah. Bank Umum Syariah adalah bank yang kegiatannya memberikan jasa dalam lalu lintas pembayaran sedangkan Bank Pembiayaan Rakyat Syariah adalah bank yang kegiatannya tidak memberikan jasa dalam lalu lintas pembayaran.

\footnotetext{
${ }^{1}$ Jurnal ini adalah bagian dari skripsi Taufan Indrasasmita, NIM: 041114146 , yang diuji pada tanggal 17 Januari 2018.
} 
PT Bank Pembangunan Daerah Jawa Timur Tbk (Bank Jatim) di dirikan dengan nama PT Bank Pembangunan Daerah Jawa Timur pada tanggal 17 Agustus 1961. Dengan adanya UndangUndang No.13 Tahun 1962 tentang "Ketentuan Pokok Bank Pembangunan Daerah", yang mengharuskan Bank Pembangunan Daerah didirikan dengan peraturan Pemerintah Daerah,maka Pemerintah Tingkat I Jawa Timur mengelvarkan Peraturan Daerah No.2 Tahun 1976. Atas dasar peraturan daerah tersebut,nama PT Bank Pembangunan Daerah Djawa Timur diubah menjadi Bank Pembangunan Daerah Jawa Timur.

Peraturan Pemerintah Daerah tersebut disahkan oleh Menteri Dalam Negeri dalam Surat Keputusan No.Pem.10/5/26-18 tanggal 31 Januari 1977 dan diumumkan dalam lembaran Daerah Tingkat I Jawa Timur Tahun 1977 Seri C No.I/C tanggal 1 Februari 1977. Peraturan Daerah tersebut mengalami beberapa kali perubahan, dan yang terakhir diubah dengan Peraturan Daerah No.11 tahun 1996, tanggal 30 Desember 1996 yang disahkan oleh Menteri Dalam Negeri dengan Surat Keputusan No.584.35-280 tanggal 21 April 1997.

Awal mula didirikannya Bank Jatim Syariah berdasarkan Surat Bank Indonesia Nomor 9/75/DS/Sb tanggal 4 April 2007 perihal : persetujuan prinsip pendirian Unit Usaha Syariah (UUS),pembukaan kantor cabang syariah dan Dewan Pengawas Syariah serta surat Bank Indonesia Nomor
9/148/DPIP/Prz/Sb tanggal 24 Juli 2007 perihal : izin pembukaan kantor cabang Syariah. Operasional Bank Jatim Syariah diresmikan pada hari Selasa tanggal 27 Agustus 2007.

Kemunculan perbankan syariah ini merupakan sebuah alternatif dalam sistem keuangan dengan karakter bebas bunga. Maka perbankan Syariah menerapkan sistem bagi hasil yang dinilai mampu meningkatkan keadilan dalam masyarakat. Semua aktivitas bisnis selalu berpotensi risiko dan return. Demikian pula perbankan syariah secara alamiah akan menghadapi peluang risiko dan return. Muhammad (2002) menyatakan bahwa jika dicermati mendalam, bank syariah merupakan bank yang sarat dengan risiko. Karena aktivitasnya banyak berhubungan dengan produk-produk bank yag mengandung banyak risiko. Berdasarkan peraturan Bank Indonesia No.13/23/PBI/2011 tentang penerapan risiko pembiayaan untuk Bank Umum Syariah, terdapat 10 macam jenis risiko yaitu: Risiko Kredit, Risiko Pasar, Risiko Likuiditas, Risiko Operasional, Risiko Hukum, Risiko Reputasi, Risiko Strategik, Risiko Kepatuhan, Risiko Imbal Hasil (Rate of Return Risk) dan Risiko Investasi.

Dalam Al Quran Allah SWT bersabda dalam QS. Al Hasyr Ayat 18 yang berbunyi:

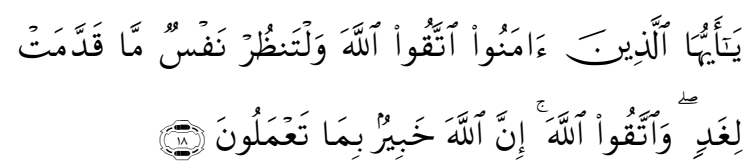

Artinya: "Hai orang-orang yang beriman, bertakwalah kepada Allah dan 
hendaklah Setiap diri memperhatikan apa yang telah diperbuatnya untuk hari esok (akhirat); dan bertakwalah kepada Allah, Sesungguhnya Allah Maha mengetahui apa yang kamu kerjakan".

\section{Rumusan Masalah}

Berdasarkan uraian latar belakang diatas, maka rumusan masalah yang dapat diajukan pada penelitian ini adalah 1. Bagaimana pengelolaan risiko pembiayaan modal kerja pada Bank Jatim Syariah?

\section{Tujuan Penelitian}

Penelitian ini betujuan untuk menjawab rumusan masalah yaitu untuk mengetahui bagaimana cara pengelolaan risiko pembiayaan modal kerja di Bank Jatim Syariah.

\section{TINJAUAN PUSTAKA}

\section{Bank Syariah}

Bank Islam pertama kali berdiri di Indonesia adalah Bank Muamalat yang telah berdiri pada tahun 1992. Perkembangan perbankan yang didasarkan kepada konsep dan prinsip ekonomi Islam merupakan suatu inovasi dalam sistem perbankan internasional. Rivai (2010:30) menyatakan bahwa menurut ketentuan yang tercantum di dalam peraturan Bank Indonesia nomor 2/8/PBI/2000, pasal 1, bank syariah adalah bank umum sebagaimana yang dimaksud dalam Undang-Undang no 7 tahun 1992 tentang perbankan dan telah diubah dengan Undang-Undang nomor 10 tahun 1998 yang melakukan kegiatan usaha berdasarkan prinsip syariat islam, termasuk unit usaha syariah dan kantor cabang bank asing yang melakukan kegiatan usaha berdasarkan prinsip syariah Islam. Menurut UU no 21 tahun 2008 bank syariah adalah bank yang menjalankan kegiatan usahanya berdasarkan prinsip syariah dan menurut jenisnya trdiri atas Bank Umum Syariah dan Bank Pembiayaan Rakyat Syariah yang dalam kegiatannya memberikan jasa dalam lalu lintas pembayaran.

\section{Fungsi, Peran dan Tujuan Bank Syariah}

Sudarsono (2008:43) menjelaskan Fungsi dan Peran Bank Syariah yang tercantum dalam AAOIFI (Accounting and Auditing Organization for Islamic Financial Institution), sebagai berikut :

1. Manajer Investasi, Bank Syariah dapat mengelola investasi dana nasabah

2. Investor, bank syariah dapat menginvestasikan dana yang dimilikinya maupun dana nasabah yang dipercayakan kepadanya

3. Penyedia jasa keuangan dan lalu lintas pembayaran, bank syariah dapat melakukan kegiatan jasa-jasa layanan perbankan sebagaimana lazimnya

4. Pelaksanaan kegiatan Sosial, sebagai ciri yang melekat pada entitas keuangan syariah, bank Islam juga memiliki kewajiban untuk mengeluarkan dan mengelola (menghimpun, mengadminstrasikan mendistribusikan) zakat serta dana dana sosial lainnya.

Peran bank syariah adalah meminimalisir kemiskinan, kebodohan, 
kebatilan, kezhaliman, dan ketidakadilan. Hal ini dapat dilihat dari kegiatan ekonomi Bank syariah yang tidak hanya mengharapkan keuntungan dunia saja tetapi juga mengharapkan keuntungan akhirat melalui kegiatan sosial (baitul Maal) dan kegiatan bisnis (baitul tamwil). Kegiatan sosial bank syariah dilakukan dengan pendayagunaan zakat, infaq, shodaqoh dan wakaf.

Tujuan dari Bank Syariah menurut Sudarsono (2008:43) adalah:

1. Mengarahkan kegiatan ekonomi umat untuk bermuamalat secara Islam, khususnya muamalat yang berhubungan dengan perbankan. Agar terhindar dari praktek-praktek riba atau jenis-jenis usaha/perdagangan lain yang mengandung unsur gharar (tipuan). Dimana jenis-jenis usaha tersebut selain dilarang dalam Islam juga dapat menimbulkan dampak negatif terhadap kehidupan ekonomi rakyat.

2. Untuk menciptakan suatu keadilan di bidang ekonomi dengan jalan meratakan pendapatan melalui kegiatan invetasi. Gunanya agar tidak terjadi kesenjangan yang amat besar antara pemilik modal dengan pihak yang membutuhkan dana.

3. Untuk meningkatkan kualitas hidup umat dengan jalan membuka peluang berusaha yang lebih besar terutama kelompok miskin, yang diarahkan kepada kegiatan usaha yang produktif, menuju terciptanya kemandirian usaha.

4. Untuk menanggulangi masalah kemiskinan, yang pada umumnya merupakan program utama dari negara-negara yang sedang berkembang. Upaya bank syariah didalam mengentaskan kemiskinan ini berupa pembinaan nasabah yang lebih menonjol sifat kebersamaan dari siklus usaha yang lengkap seperti program pembinaan pengusaha produsen, pembinaan pedagang perantara, program pembinaan konsumen, program pengembangan modal kerja dan program pengembangan usaha bersama.

5. Untuk menjaga stabilitas ekonomi dan moneter. Dengan aktivitas bank syariah akan mampu menghindari pemanasan ekonomi diakibatkan adanya inflasi, menghindari persaingan yang tidak sehat antara lembaga kevangan.

6. Untuk menyelamatkan ketergantungan umat Islam kepada bank non-syariah.

\section{Operasional Bank Syariah}

Bank Syariah memiliki operasional yang berbeda dengan bank konvensional dimana bank syariah memberikan layanan bebas bunga pada nasabahnya (Ismail, 2011:31). Bank Syariah yang memiliki fungsi sebagai penerima amanah, pengelola investasi, penyedia jasa dan sebagai pengelola fungsi sosial memiliki produk produk yang diturunkan dari fungsi-fungsi tersebut. 
Secara umum, konsep operasional bank syariah adalah penghimpun dana dan penyalur dana. Bank syariah sebagai lembaga perantara keuangan juga harus melaksanakan mekanisme penghimpunan dan penyaluran dana secara seimbang, yaitu harus sesuai dengan ketentuan perbankan yang berlaku. Dalam menjalankan operasionalnya, bank syariah tidak boleh melakukan, terlibat, mendukung, menfasilitasi, membiayai dan sebagainya dalam aktivitas yang diharamkan serta menerima dana yang diperoleh dari aktivitas yang dilarang tersebut. Selain itu, selalu berusaha menghindari transaksi yang batil, yaitu maisir (perjudian), Bai' ma'dum (melakukan penjualan atas barang yang belum dimiliki), gharar, ikhtikar, bay najasy, tadlis (penipuan) dan riba (Ryandono, 2010).

\section{Pembiayaan Bank Syariah}

Dalam Undang-Undang No.21 Tahun 2008 tentang perbankan syariah pengertian pembiayaan adalah penyediaan dana atau tagihan yang dapat dipersamakan dengan itu, berdasarkan persetujuan atau kesepakatan antara bank syariah dengan pihak lain yang mewajibkan pihak yang dibiayai untuk mengembalikan dana atau tagihan tersebut setelah jangka waktu tertentu dengan imbalan atau bagi hasil. Jenis-Jenis Pembiayaan Bank Syariah Berdasarkan sifat penggunaannya, pembiayaan dapat dibagi menjadi 2 (Antonio, 2001:160), yaitu:

1. Pembiayaan produktif, yaitu pembiayaan yang ditujukan untuk memenuhi kebutuhan produksi dalam arti luas, yaitu untuk peningkatan usaha baik usaha produksi, perdangangan, maupun investasi.

2. Pembiayaan konsumtif, yaitu pembiayaan yang digunakan untuk memenuhi kebutuhan konsumsi, yang akan habis digunakan untuk memenuhi kebutuhan.

\section{Produk-Produk Pembiayaan}

Produk-produk pembiayaan bank syariah terbagi dalam 4 bagian yang dibedakan berdasarkan tujuan penggunaannya (Karim, 2004), yaitu:

1. Berdasarkan Prinsip Jual Beli
a. Murabahah
b. Salam
C. Istishna

2. Berdasarkan Prinsip Bagi Hasil
a. Musyarakah
b. Mudharabah
c. Muzara'ah
d. Musaqah

3. Berdasarkan Prinsip Sewa
a. ljarah
b. ljarah Muntahiyyah

4. Berdasarkan Akad Pelengkap
a. Qardh
b. Hiwalah
c. Wakalah
d. Kafalah
e. Wadiah

\section{G. KELAYAKAN PEMBIAYAAN}


Untuk melaksanakan kegiatan pembiayaan secara sehat telah dikenal dengan adanya prinsip 5C (Mulyono, 2000), kelima prinsip yang klasik ini meliputi:

1. Character

2. Capacity

3. Capital

4. Collateral

5. Condition of Economics

Pengendalian Pembiayaan Bermasalah

Pengendalian risiko pembiayaan dilakukan untuk menjaga agar pembiayaan yang diberikan lancar dan produktif, pengendalian risiko pembiayaan dapat dilakukan dengan cara:

1. Preventive Control of Finance, yaitu pengendalian yang dilakukan dengan tindakan pencegahan sebelum pembiayan tersebut bermasalah, upaya tersebut dilakukan dengan cara :
a. Menetapkan kebijakan pembiayaan
b. Meningkatkan kualitas SDM
C. Asuransi
d. Penagih intensif
e. Manajemen kolektibilitas prosedur dan

2. Repressive Control of Finance, yaitu pengendalian dan pengelolaan pembiayaan dilakukan melalui tindakan penyelesaian setelah pembiayaan tersebut bermasalah, upaya tersebut dapat dilakukan dengan cara :

a. Rescheduling b. Reconditioning

C. Restructuring

\section{Definisi Manajemen Risiko}

Manajemen risiko adalah rangkaian prosedur dan metedologi yang digunakan untuk mengidentifikasi, mengukur, memantau dan mengendalikan risiko yang timbul dari kegiatan usaha bank (Sulhan dan Siswanto, 2008:150). Pemahaman tentang manajemen risiko pembiayaan dapat dipahami apabila terlebih dahulu memahami definisi dari masing-masing kata yang terkait didalamnya, yaitu manajemen, risiko, dan pembiayaan.

Manajemen menurut George R. Terry, didefinisikan sebagai proses perencanaan, pengorganisasian, penggerakan serta pengawasan aktifitasaktifitas suatu organisasi dalam upaya mencapai suatu koordinasi sumbersumber daya manusia dan sumber daya alam dalam hal pencapaian sasaran secara efektif dan efisien (Hasibuan, 2005:2). Sementara menurut James F. Stoner,manajemen merupakan proses perencanaan, pengorganisasian dan penggunaan sumber daya organisasi lainnya agar mencapai tujuan organisasi yang telah ditetapkan (Hasibuan, 2005:3).

Dari definisi ahli diatas dapat disimpulkan bahwa manajemen merupakan proses perencanaan, pengorganisasian, penggerakan dan pengendalian/pengawasan atas upayaupaya anggota sebuah organisasi dan atas penggunaan sumber daya yang 
terdapat pada organisasi tersebut untuk mencapai tujuan tertentu, yang mana proses pencapaian tujuan tersebut melalui keempat fungsi manajemen itu (Suhendra dan Murdiyah, 2006:2).

\section{FUNGSI DAN TUJUAN MANAJEMEN RISIKO}

Secara garis besar manajemen risiko berfungsi sebagai berikut (Karim, 2007:255):

a. Menunjang ketepatan proses perencanaan dan pengambilan keputusan

b. Menunjang efektivitas perumusan kebijakan sistem manajemen dan bisnis

c. Menciptakan Early Warning System untuk meminimalisir risiko

d. Menunjang kualitas pengelolaan dan pengendalian pemenuhan kesehatan bank

e. Menunjang penciptaan/pengembangan keunggulan kompetitif

f. Memaksimalisasi kualitas asset

Sementara itu, adapun tujuan manajemen risiko antara lain (Salim, 2003:197)

a. Memastikan bank tidak mengalami kerugian yang bersifat unacceptable

b. Meminimalisasi kerugian dari berbagai risiko yang bersifat uncontrolled

c. Untuk kelangsungan hidup perusahaan

d. Ketenangan dalam berpikir atau mengurangi keresahan

e. Memperkecil biaya

f. Menstabilisasi pendapatan perusahaan
g. Memperkecil atau bahkan meniadakan ganguan dalam berproduksi

h. Mengembangkan pertumbuhan perusahaan

\section{Risiko Pembiayaan}

Peraturan Bank Indonesia No.13/23/PBI/2011 tentang penerapan Risiko Pembiayaan untuk Bank Umum Syariah dan Unit Usaha Syariah, terdapat 10 macam jenis risiko, yaitu:

1. Risiko Kredit

2. Risiko Pasar

3. Risiko Likuiditas

4. Risiko Operasional

5. Risiko Hukum

6. Risiko Reputasi

7. Risiko Strategik

8. Risiko Kepatuhan

9. Risiko Imbal Hasil

10. Risiko Investasi

\section{Proses Manajemen Risiko}

Proses manajemen risiko merupakan tindakan dari seluruh entitas terkait didalam organisasi (Idroes, 2008:7). Untuk menerapkan proses manajemen risiko, pada tahap awal bank harus secara tepat mengenal dan memahami serta mengidentifikasi seluruh risiko, baik yang sudah ada maupun yang mungkin timbul dari suatu bisnis atau produk baru bank. Selanjutnya secara bertahap, bank perlu melakukan pengukuran, pemantauan, dan pengendalian risiko.

\section{Proposisi}

Pembiayaan modal kerja pada Bank Jatim Syariah memiliki banyak risiko. 
Pengelolaan risiko yang baik membuat risiko pembiayaan modal kerja dapat dikendalikan.

\section{METODE PENELITIAN}

\section{Pendekatan Penelitian}

Pendekatan penelitian yang digunakan dalam penelitian ini menggunakan pendekatan kualitatif. Menurut Yin (2013) pendekatan kualitatif adalah pendekatan dengan menggunakan data berupa kalimat tertulis atau lisan,peristiwa-peristiwa, pengetahuan atau proyek studi yang bersifat deskriptif.

Strategi yang digunakan dalam penelitian ini adalah studi kasus. Menurut Yin (2013), studi kasus merupakan strategi yang paling cocok bila pertanyaan suatu penelitian berkenaan dengan what dan how, bila penelitian hanya memiliki sedikit peluang untuk mengontrol peristiwaperistiwa yang akan di selidiki dan bila mana focus penelitian terletak pada fenomena kontemporer (masa kini) di dalam konteks kehidupan nyata.

\section{Ruang Lingkup Penelitian}

Penelitian yang dimaksud adalah untuk menjawab rumusan masalah yang dimana dijadikan acuan dalam penelitian ini. Ruang Lingkup penelitian terbatas memfokuskan pada seberapa besar faktor risiko yang diterima bank syariah dalam melakukan pembiayaan modal kerja.

\section{Jenis Dan Sumber Data}

Data yang dihimpun oleh penulis adalah data primer (utama) dan sekunder (penunjang). Data primer adalah data yang diperoleh langsung dari sumbernya melalui wawancara dengan pihak Bank Syariah. Data tersebut dikumpulkan dengan wawancara, dimana metode ini memungkinkan peneliti bertatap muka langsung dengan informan untuk mendapatkan informasi yang mendalam sehingga dapat dipertanggung jawabkan validitas datanya. Data sekunder dari penelitian ini diperoleh dari studi kepustakaan yang memuat tentang analisis risiko dan pembiayaan modal kerja. Sumber data dalam penelitian ini diperoleh dari:

a. Data Primer

Didapatkan dengan wawancara kepada pihak bank syariah. Wawancara dapat dilakukan terhadap kepala divisi bagian pembiayaan atau pihak-pihak yang terkait dengan pembiayaan.

b. Data Sekunder

Data tertulis pada penelitian ini berupa jurnal, artikel atau buku-buku yang dapat menjadi referensi bagi peneliti tentang analisis risiko pembiayaan di bank syariah.

\section{Unit Analisis}

Tujuan adanya unit analisis adalah mencari ciri khusus yang ada dalam ramuan konteks yang unik dan menggali informasi yang akan menjadi dasar dari rancangan dan teori yang muncul. Dalam pengambilan informan peneliti memilih orang atau individu yang dianggap paling tahu tentang apa yang 
diharapkan mengenai topik yang diteliti.

Dalam penelitian ini unit analisis adalah Proses Manajemen Risiko Pembiayaan Modal Kerja di Bank Jatim Syariah.

\section{Teknik Pengumpulan Data}

1. Wawancara

Wawancara memang merupakan sumber informasi yang esensial bagi studi kasus. Dalam wawancara, peneliti dapat bertanya kepada koresponden kunci tentang fakta-fakta suatu peristiwa disamping opini mereka mengenai peristiwa yang ada. Pada beberapa situasi, peneliti bahkan bisa meminta responden untuk mengetengahkan pendapatnya sendiri terhadap peristiwa tertentu dan bisa menggunakan proposisi tersebut sebagai dasar penelitian selanjutnya. Responden tidak hanya bisa memberi keterangan sesuatu kepada peneliti tetapi juga bisa memberi saran tentang sumber-sumber bukti lain yang mendukung, serta menciptakan akses terhadap sumber yang bersangkutan. (Yin, 2013:109)

\section{Dokumentasi}

Informasi documenter tentunya relevan untuk setiap topic studi kasus. Tipe informasi ini bisa menggunakan berbagai bentuk dan hendaknya menjadi objek rencana-rencana pengumpulan data yang eksplisit. Penggunaan dokumen yang paling penting adalah untuk mendukung dan menambah bukti dari sumber-sumber lain. (Yin, 2013:103)

\section{Teknik Keabsahan Data}

\begin{abstract}
Triangulasi dalam pengujian kredibilitas ini diartikan sebagai pengecekan data dari berbagai sumber dengan berbagai cara dan waktu. (Sugiyono, 2015:372). Dalam penelitian ini, peneliti menggunakan triangulasi sumber karena mampu mendukung selama proses penelitian berlangsung. Maksud triangulasi sumber yaitu pengujian kredibilitas data dengan cara mengecek data yang diperoleh melalui beberapa sumber.
\end{abstract}

\section{Teknik Analisis Data}

Analisis data dalam penelitian kualitatif dilakukan sejak sebelum memasuki lapangan, selama dilapangan dan setelah selesai dilapangan. Tetapi dalam kenyataannya, analisis data kualitatif berlangsung selama proses pengumpulam data dari pada setelah pengumpulan data. (Sugiyono, 2015:336). Miles and Huberman mengungkapkan bahwa aktivitas dalam analisis data kualitatif dilakukan secara interaktif dan berlangsung secara terus menerus sampai tuntas. Terdapat 3 aktivitas dalam analisis data, yaitu (Sugiyono, 2015:338):

1. Reduksi Data

2. Penyajian Data

3. Penarikan Kesimpulan

IV. HASIL ANALISIS DAN PEMBAHASAN Hasil Analisis

Manajemen risiko adalah rangkaian prosedur dan metedologi yang digunakan untuk mengidentifikasi, mengukur, memantau dan mengendalikan risiko yang timbul dari 
kegiatan usaha bank (Sulhan dan Siswanto, 2008:150). Penerapan manajemen risiko pada bank umum diatur dalam peraturan Bank Indonesia Pasal 28 UU 21 Tahun 2008 (1) yang berisi Bank Syariah dan UUS wajib menerapkan manajemen risiko, prinsip mengenal nasabah dan perlindungan nasabah. Hal ini bertujuan sebagai upaya bank untuk meningkatkan efektivitas kinerja bank serta menjaga kesehatan masing-masing bank.

\section{Pembahasan}

Penerapan manajemen risiko pada bank umum diatur dalam Peraturan Bank Indonesia Pasal 28 UU 21 Tahun 2008 yang berisi Bank Syariah dan UUS wajib menerapkan manajemen risiko, prinsip mengenal nasabah dan perlindungan nasabah. Hal ini bertujuan sebagai upaya bank untuk meningkatkan efektivitas, kinerja bank serta menjaga kesehatan dari masing-masing bank.

Risiko yang mungkin terjadi dapat menimbulkan kerugian bagi perusahaan, apabila tidak dideteksi serta dikelola sebagaimana mestinya. Oleh karena itu peran manajemen risiko sendiri sangatlah penting dalam mengendalikan risiko-risiko yang mungkin timbul dalam melaksanakan kegiatan usahanya, agar memperoleh hasil yang maksimal dari rencana perusahaan. Dengan demikian manajemen risiko juga berfungsi sebagai filter atau pemberi peringatan secara dini terhadap kegiatan usaha.

\section{Identifikasi Risiko}

Proses ini merupakan langkah awal dalam memulai identifikasi dengan melakukan analisis pada karakteristik risiko yang melekat pada aktivitas fungsional dan juga risiko dari produk dan kegiatan usaha. Salah satu aspek penting dari identifikasi risiko adalah membuat daftar risiko yang mungkin terjadi sebanyak mungkin serta menganalisisnya secara aktif agar tidak timbul risiko yang berlebihan

Dari identifikasi risiko yang sudah dilakukan, daftar risiko yang sering muncul dalam Pembiayaan Modal Kerja adalah risiko kredit atau gagal bayar. Setelah risiko tersebut muncul, akan diketahui apa saja yang menyebabkan nasabah tersebut gagal bayar, faktor-faktor yang muncul di BJS adalah karena usaha nasabah bangkrut, nasabah melakukan rekayasa usaha, dan pemindahan modal yang tidak semestinya.

Ada beberapa faktor yang menyebabkan nasabah mengalami kendala gagal bayar, penyebabnya adalah :

1. Faktor usaha nasabah yang bangkrut

2. Perputaran uang yang tidak semestinya

3. Rekayasa usaha

4. Kekurangan SDM

5. Usaha yang dijalankan usaha musiman Selain risiko kredit, terdapat dua risiko lain yang muncul selama proses pembiayaan, yaitu risiko reputasi dan risiko likuiditas. Risiko reputasi ini berkaitan dengan status Bank Jatim Syariah sebagai 
bank pemerintah. Sedangkan risiko likuiditas berkaitan dengan Non Performing Loan (NPL), yaitu kondisi dimana bank tidak memiliki cukup dana dalam memberikan pembiayaan, sehingga secara langsung akan menggunakan Cadangan Kerugian Penurunan Nilai (CKPN).

\section{Analisis Risiko}

Setelah melakukan identifikasi risiko, maka tahap selanjutnya adalah pengukuran risiko dengan cara melihat potensial terjadinya seberapa besar kerusakan dan probabilitas terjadinya risiko tersebut. Proses ini dilakukan dengan melakukan evaluasi secara berkala terhadap kesesuaian asumsi, sumber data dan prosedur yang digunakan untuk mengukur risiko, penyempurnaan terhadap sistem pengukuran risiko apabila terdapat perubahan kegiatan usaha, produk, transaksi dan faktor risiko yang bersifat material. Dalam melakukan analisis risikonya, BJS melihat dari kemampuan bayar nasabah, jadi tidak ada ketentuan tetap yang diharuskan kepada nasabah dalam menentukan jumlah angsuran. Bank Jatim Syariah menggunakan enam analisa pengukuran, yaitu :

1. Analisa Kevangan

2. Analisa Karakter

3. Analisa Manajemen

4. Analisa Fasilitas

5. Analisa Kondisi Lingkungan Usaha

6. Analisa Agunan atau Jaminan

\section{Pengendalian Risiko}

Dalam kegiatan pembiayaan modal kerja, Bank Jatim Syariah senantiasa berhadapan dengan berbagai risiko dan harus diakui bahwa sesungguhnya industri perbankan adalah suatu industri yang sarat dengaan risiko, terutama risiko nasabah gagal bayar. Risiko yang sudah terdeteksi oleh manajemen dari laporan yang diterima dari pihak nasabah, maka akan disikapi dan ditanggulangi secepatnya. Pihak Bank Jatim Syariah menggunakan prinsip 3R dalam melakukan pengendalian risikonya, yaitu :

1. Reschedulling

2. Restructuring

3. Reconditioning

\section{Evaluasi Risiko}

Pada tahap ini dilakukan dengan cara mengevaluasi pengukuran risiko yang terdapat pada kegiatan usaha bank serta pada kondisi efektivitas proses manajemen risiko. Hal-hal yang harus diperhatikan dalam pemantauan ini adalah melihat kemampuan bank untuk menyerap risiko atau kerugian yang timbul, serta melihat kemampuan kinerja sumber daya manusia yang terdapat didalam banj untuk mengantisipasi risiko yang mungkin terjadi. Selain itu bank juga harus menyiapkan sistem dan prosedur yang efektif untuk mencegah terjadinya gangguan dalam proses pemantavan risiko agar hasilnya dapat menyempurnakan proses manajemen risiko yang terdapat pada bank tersebut. Proses ini dilaksanakan dengan 
memperhatikan perubahan yang ada pada kegiatan pembiayaan yang sedang dilakukan. Untuk proses evaluasi ini Bank Jatim Syariah biasa menggunakan pembiayaan jenis Ballon Payment, jadi disini nasabah hanya akan membayar marginnya saja selama usahanya belum menghasilkan, setelah usahanya menghasilkan maka jumlahnya akan ditambah dengan jumlah pokok. Selain Ballon Payment, Bank Jatim Syariah juga menggunakan pendekatan emosional kepada nasabahnya agar pihak nasabah selalu merasa dekat dengan pihak bank, sehingga diharapkan nasabah akan menjalankan usahanya dengan nyaman.

\section{SIMPULAN}

Berdasarkan hasil analisis dan pembahasan pada bab sebelumnya, maka dapat disimpulkan sebagai berikut:

1. Manajemen risiko pembiayaan modal kerja pada Bank Jatim Syariah dapat diketahui melalui tahapan-tahapan manajemen risiko, yaitu mulai identifikasi risiko, analisis risiko, pengendalian risiko dan evaluasi risiko.

2. Risiko utama yang dihadapi oleh pembiayaan modal kerja Bank Jatim Syariah adalah risiko kredit atau gagal bayar. Risiko ini disebabkan karena kondisi nasabah yang mengalami kebangkrutan usaha, perputaranan vang yang tidak semestinya, rekayasa usaha, kekurangan SDM dan usaha musiman. Selain risiko kredit terdapat risiko reputasi yang berkaitan dengan reputasi Bank Jatim Syariah sebagai bank pemerintah. Lalu risiko likuiditas yang berkaitan dengan kondisi Non Performing Loan (NPL).

3. Untuk meminimalisir risiko yang timbul, pihak Bank Jatim Syariah telah melakukan berbagai macam analisis agar risiko yang terjadi dapat dihindarkan. Analisis yang dilakukan oleh BJS dapat dilihat dari risiko-risiko yang muncul, baik sebelum terjadinya risiko tersebut, maupun yang sudah terjadi. Ini dilakukan untuk memudahkan pihak bank dalam menghindari segala macam risiko yang mungkin saja bisa terjadi

Adapun saran yang dapat diberikan dari penelitian ini adalah diharapkan penelitian selanjutnya bisa mendapatkan informasi yang lebih mendalam terkait dengan pembiayaan modal kerja di Bank Jatim Syariah. Hal ini diperlukan agar dapat memberikan manfaat bagi penelitian selanjutnya dan juga Bank Jatim Syariah.

\section{DAFTAR PUSTAKA}

Al-Quran dan Terjemahannya (revisi terbaru Departemen Agama RI dengan Transliterasi Arab-Latin (rumy)). 2000. Semarang: CV. Asy Syifa'.

Adiwarman A. Karim, Bank Islam: Analisis Fiqih dan Keuangan, (Jakarta: PT. RajaGrafindo Persada, 2007:255)

Antonio, Muhammad Syafi'i. 2001. Bank Syariah: Dari Teori ke Praktik. Jakarta: Gema Insani Pers 
Bank Indonesia. 2008. Undang-Undang No. 21 Tahun 2008: tentang Perbankan Syariah.

Hasibuan, Malayu S.P. Manajemen, Dasar, Pengertian dan Masalah, (Jakarta:Bumi Aksara, 2005:2)

Idroes, Ferry N. 2008:7. Manajemen Risiko Perbankan: Pemahaman 3 Pilar Kesepakatan Basel II Terkait Aplikasi Regulasi dan Pelaksanaannya di Indonesia.

Ismail. 2011. Perbankan Syariah. Jakarta: Kencana

Muhammad, 2002. Manajemen Bank Syariah. Yogyakarta: Unit Penerbit dan Percetakaan Sekolah Tinggi IImu Manajemen YKPN

Mulyono, Teguh. P. 2000. Manajemen Perkreditan Bagi Bank Komersil. BPFE Yogyakarta

Peraturan Bank Indonesia Nomor 13/23/PBI/2011 Tentang Penerapan Manajemen Risiko bagi Bank Umum Syariah dan Unit Usaha Syariah, diakses pada 18 Juli 2017 dari

http://www.bi.go.id/NR/rdonlyres/ pbi_13231 fl.pdf

Rivai, Veithzal. 2010. Islamic Banking. Sistem Bank Islam Bukan Hanya Solusi Menghadapi Krisis Namun Solusi dalam Menghadapi
Berbagai PersoalanPerbankan dan Ekonomi Global. Jakarta: Bumi Aksara

Ryandono. 2010. Peran dan Pengaruh Penghimpunan Dana terhadap Penyaluran Dana dan Faktor Kinerja Bank serta Kesejahteraan Karyawan Bank Islam di Indonesia. Disertasi tidak diterbitkan. Surabaya Program Doktor Pasca Sarjana Universitas Airlangga Surabaya

Salim, Abbas. Asuransi dan Manajemen Risiko, (Jakara, 2003:197)

Sudarsono, Heri. 2008. Bank dan Lembaga Kevangan Syariah. Yogyakarta: Ekonisia

Sugiyono. 2015. Metode penelitian pendidikan.

Suhendra dan Murdiyah. Manajemen Sumber Daya Manusia, (Jakarta:UIN Press, 2006:2)

Sulhan, M., dan Ely Siswanto. 2008. Manajemen Bank : Konvensional dan Syariah. UIN Malang Press: Malang

Yin, Robert K. 2013. Studi kasus:desain dan metode. Jakarta: Rajawali Press

Ascarya. 2013. Akad \& Produk Bank Syariah. Jakarta: Rajawali Pers..

Undang-undang Dasar Negara Republik Indonesia Tahun

1945. 